\title{
Stock Return Predictability with Financial Ratios: An Empirical Study of Listed Manufacturing Companies in Sri Lanka
}

\author{
Saradhadevi Anandasayanan \\ Senior Lecturer, Dept. of Financial Management \\ University of Jaffna, Sri Lanka \\ E-mail: sayananakshi@yahoo.com
}

Received: December 4, 2018 Accepted: December 20, 2018 Published: December 27, 2018

doi:10.5296/ijafr.v8i4.14137

URL:https://doi.org/10.5296/ijafr.v8i4.14137

\begin{abstract}
This study attempts to investigate financial ratios' predictive power, using the yearly time series data during the period of 2012-2017 for 33 listed manufacturing companies in Colombo Stock Exchange. This study specifically identifies the financial ratios, which are acknowledged as the predictors of stock returns in the share market, to test the stock return predictability. The financial ratios include the ratio of dividend yield, earnings per share, and earnings yield which are most useful and effective on stock return predictability in order to cover a wide range of predictions which have been used by all most all the previous researches. The stock return predictability is analyzed by regressing the dividend yield, earning per share and earning yield respectively on the yearly stock returns from 2012 to 2017. The results show high predictability power, since the $\mathrm{R}^{2}$-value is high and the coefficients are very significant and autocorrelation corrected standard errors. The results reveal that the three ratios hold a somehow predictive power regarding stock returns of the Listed Manufacturing Companies in Colombo Stock Exchange.
\end{abstract}

Keywords: Dividend yield, Earning yield, Earning per share, Stock return

\section{Introduction}

\subsection{Background of the Study}

Stock Market plays a very major contribution in the economic growth of a country. According to Schrempf (2010) there was significant economic after math of the existence of stock return predictability. The accounting information will help investors to predict future events. In addition, financial scholars are often interested in examining the financial ratios to 
able to use them in predicting future stock returns. However this kind of research is very less in developing the stock exchange and the emerging market, especially in Sri Lanka. Therefore this study is going to fill this gap by a further study on Stock return predictability with financial ratios.

\subsection{Problem Statement}

Predicting stock return using financial ratios is well renowned in developed countries like UK and USA. Goyal and Welch (2007) analysed in theirprevious study and recommended that ability to predict the equity premium was not apparent even before the 1990s. Even though empirical research has been evidence on predicting stock return using financial ratiosin Sri Lankan context, there have been a very few of studies in Sri Lankan stock market (except Samarakoon (1998) and Chaturika Seneviratne and Nimal. Therefore, the objective of this study is to reexamine whether the stock returns is explained by ratios in Sri Lankan context on Listed Manufacturing Companies for the period from 2012 to 2017. Hence this study seeks to examine the relationship between financial ratio such as earning yield, dividend yield, and earnings per share on stock return of manufacturing companies listed in Colombo Stock Exchange. The study will attempt to answer the following research question: To what extent the financial ratio analysis predict the stock return of the Listed Manufacturing Companies in Sri Lanka.

\subsection{Research Question}

Based on the research problem, the following research questions are formulated.

i. Do the financial ratios predict the stock return of manufacturing industries in Sri-Lanka?

\subsection{Objectives of This Study}

Main objective of the study is to find out the predicting ability of the financial ratios on the stock return of manufacturing industries in Sri-Lanka.

Sub objectives are

i. To compute the industry averages, in respect of earning per share, dividend Yield and earning yield.

ii. To find out the stock Return of manufacturing companies.

\section{Empirical Literature on Financial Ratio and Stock Return Predictability}

Wijesunderaet al (2015) carried out a research on the topic of Predictability of Stock Returns Using Financial Ratios: Empirical Evidence from Colombo Stock Exchange. This study applied ordinary least squares (OLS) techniques to estimate the predictive regressions in form of simple and multiple models of panel data sets. The results highlighted that ROE, EPS and MV/BV had a significant positive relationship with the stock return which is followed by a simple equation to predict the future stock returns.

Perera and Thrikawala (2010) carried out a research on the topic "an empirical study of the Relevance of Accounting Information on Investor's Decisions based on the Colombo Stock 


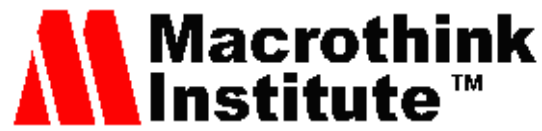

International Journal of Accounting and Financial Reporting

ISSN 2162-3082

Exchange, Sri Lanka." The relevance of accounting data was calculated by correlation coefficient with Market Price per Share and selected accounting information such as Earning per Share, Return on Equity and Earning Yield. The findings revealed that there was a relationship between Accounting Information and Market Price per Share. Therefore it was also support of the relationship between accounting variables and stock return.

Kuo et al, (2001) studied about "An intelligent decision support system for stock trading by using social and genetic algorithm based on fuzzy neural network and artificial neural networks "to maintain a system of consultation, sale or purchase of stock market shares had been attempted. The researcher, in (1998), an article with the same title, regardless of genetic algorithms had done. In the paper, a questionnaire with fuzzy Delphi method to the use of expert opinion was used to predict the stock price.

Refenes et al., (1994) have done a study about the stock price behavior modeling by neural networks. Its performance had been compared with the regression models. The results revealed that neural networks had better performance than the statistical techniques and models were superior.

Tan et al., (1995), the system had been designed significant changes in the short-term stock price forecasts. The events took place before processing and neural network modeling the situation very well benefit estimates.

MacMillán (2001) found out the nonlinear relationship between stock returns and changes can be made based on the logarithmic transformed into simple linear equations. For the reason, the nonlinear relationship between the output variables for instanceinterest, dividends, and return on equity, return on assets and the ratio of dividends to stock price was determined through a simple logarithmic model.

Kanas and Yannopouluos (2001) in their study the linear and nonlinear models for the prediction of monthly stock returns New York Stock Exchange was compared.

According to Spiro (1990) America shares in the stock market was affected by changes in interest rates, stock price forecasting model for the long-term and short-term talent.

Lewellen carried out a on the topic of A study of financial ratios to predict stock returns. The study period was the year 2000 -1995. The results revealed that a significant dividend yields predicted stock returns, the price earnings ratio of book value to market value had a little ability to predict stock returns.

Olsen and Mossman conducted a study on the topic of predict stock returns using financial ratios. The study of neural network model and ordinary least squares technique was applied to predict stock returns. 1976 to 1993 study period. The results revealed that the neural network technique to predict than other technologies, more acceptable results were displayed and forecast error was significantly reduced.

Samarakoon(1998) conducted a study about the predictability of the profitability of companies in the Stock Exchange using their financial ratios. In this study, he found that a financial ratio analysis had a high correlation with profitability and predictability by multiple 
regression financial ratios, the results of this study indicate a high impact on stock return in the anticipated financial ratios.

\subsection{Data Description}

The secondary data will be used for the study. Number of companies in CSE were identified and segregated by sectors. From the above sectors the researcher decided to take only the manufacturing sector. There are 40 manufacturing companies in CSE. Out of the 40 companies 33 companies were randomly selected for the study. The data representing the periods of 2012 to 2017 were taken into consideration and the average value of each item was considered for the purpose of ratio computation and analysis.

\subsection{Variables of the Study}

A variable is a measure whose value may vary in different scope from one watching to another. So the requirement of doing a research is to determine and define each of the research variables. The variables considered in the present study are divided into two groups of dependent and independent variables. A dependent variable is one whose changes are affected by the independent variables. In this study, stock returns (R) in the Manufacturing companies listed on Colombo Stock Exchange is selected as the dependent variable that is calculated as follows:

\subsubsection{Stock Return (SR)}

Following Lewellen (2001) and Kheradyar et al, (2011) researcher has used stock return as dependent variable. Stock return is calculated by dividing capital gain along with dividend per share on market price per share. Following is used to calculate the stock returns.

$$
\mathrm{SR}=\mathrm{DPs}+\text { capital gain/market price }
$$

\subsubsection{Dividend Yield (DY)}

Subsequent Kheradyar et al, (2011) second independent variable in this study is Dividend yield which is intended as dividing dividend per share on market price per share. If market price is lower than dividend yield will be higher and give a riskier signal for investment. Contrast to higher dividend yield is low dividend yield; such happen when market price per share is higher than dividend yield and gives an optimistic view for investment.

The following formula demonstrates how to calculate dividend yield:

Dividend Yield $(\%)=($ Dividend per Share $/$ Market rate per share $) \times 100$

\subsubsection{Earning Yield (EY)}

The existing literatures lay foundations of the predictive power of earning yield on stock return, and find out the association between earning yield and stock return is considerable, because earning yield plays as a risk factor in relation with stock return. Moreover, the earning yield can express the efficiency of market that has a vital role in emerging markets, thus this study uses earning yield as the empirical predictor of stock return. 


\subsubsection{Earning per Share (EPS)}

Earnings per share (EPS) ratio measures how many dollars of net income have been earned by each share of common stock. It is computed by dividing net income less preferred dividend by the number of shares of common stock outstanding during the period.

\section{Hypotheses of the Study}

In this study, the following hypotheses are considered by the researcher.

The main objective of this study is to find out whether there is a significant relationship between stock returns and financial ratios in the listed Manufacturing companies in Colombo Stock Exchange or not.

The following hypotheses are formulated:

$\mathrm{H}_{1}$ : There is a significant relationship between stock returns and earning yield in the listed Manufacturing companies in Colombo Stock Exchange.

$\mathrm{H}_{2}$ : There is a significant relationship between stock returns and dividend yield in the listed Manufacturing companies in Colombo Stock Exchange

$\mathrm{H}_{3}$ : There is a significant relationship between stock returns and Earning per share in the listed Manufacturing companies in Colombo Stock Exchange

\subsection{Model Specification}

After the careful study of theoretical and review of literature the following conceptual model is formulated to depict the relationship between Stock return and Financial Ratio.



Figure 1.Conceptualization model

Source: Developed by Researcher

\section{Data Analysis}

\subsection{Descriptive Statistics}

Descriptive statistics are used to describe the basic features of the data collected for this study. The common descriptive statistics include means, maximum, minimum, standard deviation, skewness and kurtosis. 
Table 1. Descriptive statistics

\begin{tabular}{lllll}
\hline & DY & E_Y & EPS & RETURN \\
\hline Mean & 0.312230 & 0.270800 & 6.428107 & 0.041430 \\
\hline Median & 0.127353 & 0.074345 & 2.785000 & 0.025344 \\
\hline Maximum & 4.342222 & 4.324444 & 49.65000 & 1.136364 \\
\hline Minimum & -0.813200 & -0.853200 & -14.61000 & 0.000000 \\
\hline Std.Dev. & 0.819612 & 0.810597 & 8.268749 & 0.099315 \\
\hline Skewness & 2.388883 & 2.490171 & 1.497622 & 8.830138 \\
\hline Kurtosis & 10.64584 & 11.26604 & 6.572316 & 90.12879 \\
\hline Jarque-Bera & 663.8349 & 760.5722 & 177.4856 & 64543.72 \\
\hline Probability & 0.000000 & 0.000000 & 0.000000 & 0.000000 \\
\hline Sum & 61.19712 & 53.07682 & 1259.909 & 8.120350 \\
\hline SumSq.Dev. & 130.9938 & 128.1283 & 13332.58 & 1.923387 \\
\hline Observations & 198 & 198 & 198 & 198 \\
\hline
\end{tabular}

Table 1 presents the Descriptive statistics of the data related to this study. Dividend yield's mean, median, minimum and maximum values are found respectively $0.312230,0.127353$, 4.342222 and -0.813200 . Besides standards deviation is found 0.819612.Skewnes and Ketosis are found 2.388883 and 10.64584 respectively. Earning yield's mean, median maximum and minimum values are reckoned to be respectively $0.270800,0.074345,4.324444$ and -0.853200 . Besides standard deviation, skewness, kurtosis values are respectively perceived on 0.810597 , 2.490171, and 11.26604.Mean value of Earning per share, firm size and stock return and return on equity are respectively seen to be 6.428107, 9.220301, 0.041430 and 0.113827.Median value of these variables is Maximum and minimum value of these variables are respectively to pairs each (49.65000 and -14.61000), (10.21193 and 7.563862), (1.136364 and 0.000000) and (0.901515 and -0.398650$)$.

\subsection{Augmented Dickey - Fuller Unit Root Test and PP Test}

Researcher tests for the presence of unit roots and identify the order of integration for each variable using the Augmented Dickey-Fuller (ADF). Since majority of time series econometric techniques are built upon that the time series variables are stationary, when we apply standard estimations and test procedures in the dynamic time series model, as the first step, it is necessary to examine the stationary property of a series. A stationary series can be defined as one with a constant mean, constant variance and constant auto covariance for each given lag. Many approaches can be performed to detect the stationarity of a time series. But 
the most popular methods are Augmented Dickey-Fuller (ADF) test, Phillips-Perron (PP) test and Kwiatkowski, Phillips, Schmidt, and Shin (KPSS, 1992) test. Table 2 presents the results of the ADF test and PP test.

Table 2.Results of the ADF test and PP test

\begin{tabular}{|c|c|c|c|c|c|c|c|c|}
\hline \multirow[t]{5}{*}{ Variables } & \multicolumn{4}{|c|}{ Augmented Dickey-Fuller test Statistics } & \multicolumn{4}{|c|}{ Phillips -Perron test Statistics } \\
\hline & \multicolumn{4}{|c|}{ Null Hypotheses: Variable is non Statinary } & \multicolumn{4}{|c|}{ Null Hypotheses: Variable is non Statinary } \\
\hline & \multicolumn{2}{|l|}{ Level } & \multicolumn{2}{|c|}{ First Difference } & \multicolumn{2}{|l|}{ Level } & \multicolumn{2}{|c|}{ First Difference } \\
\hline & Test & $\mathrm{P}$ & Test & $\mathrm{P}$ & Test & $\mathrm{P}$ & Test & $\mathrm{P}$ \\
\hline & Statistics & Value & Statistics & Value & Statistics & Value & Statistics & Value \\
\hline \multicolumn{9}{|l|}{ Dividend } \\
\hline Yield & -2.360188 & 0.1537 & -20.69383 & 0.0000 & -2.779252 & 0.0619 & -28.68018 & 0.0000 \\
\hline EPS & -4.070494 & 0.0012 & -15.50669 & 0.0000 & -5.640863 & 0.0000 & -36.30200 & 0.0000 \\
\hline EY & -3.157590 & 0.0231 & -29.65065 & 0.0000 & -3.396552 & 0.0115 & --31.34284 & 0.0000 \\
\hline SR & -1.676921 & 0.4425 & -6.580274 & 0.0000 & -2.125666 & 0.2347 & -33.57878 & 0.0000 \\
\hline
\end{tabular}

Here all $p$ values are equal to Zero. Thus the variables don't have the unit root.

\subsection{Multicolinearity Test}

Multi co linearity can be measured using Variance Inflation Factor or Tolerance test. In this study, VIF was used.

Table 3

\begin{tabular}{lll}
\hline & Coefficient & Centered \\
\hline Variable & Variance & VIF \\
\hline $\mathrm{C}$ & 201.8214 & NA \\
\hline Div.Yield & 0.045368 & 1.251836 \\
\hline Earn. Yield & 21.66144 & 1.198335 \\
\hline EPS & 10.90520 & 1.099564 \\
\hline Stock Return & 0.424679 & 1.072716 \\
\hline
\end{tabular}

According to the Table3 VIF values are below 10 and when VIF values are less than 10 then there is no multi- co linearity problem. 


\section{Mll Macrothink}

International Journal of Accounting and Financial Reporting

ISSN 2162-3082

2018, Vol. 8, No. 4

\subsection{Least Square Regression Analysis}

To find out the impact of financial ration on stock return of the manufacturing listed companies, regression analysis was carried out and the Result of the regression presents in the Table 4.

Table 4. Results of OLS regression summary

Dependent Variable: stock return

Method: Least Squares

Sample: 1198

Included observations: 198

\begin{tabular}{lllll} 
Variable & \multicolumn{2}{l}{ Coefficient Std. Error } & t-Statistic & Prob. \\
\hline C & 40.87346 & 17.38711 & 2.350791 & 0.0198 \\
\hline DY & -0.108152 & 0.041274 & -2.620365 & 0.0095 \\
\hline EY & 1.611117 & 0.306184 & 5.261919 & 0.0000 \\
\hline EPS & -0.197892 & 0.086024 & -2.300441 & 0.0225 \\
\hline R-squared & 0.546015 & Mean dependent var & -23.48303
\end{tabular}

Adjusted R-squared 0.529111 S.D. dependent var $\quad 62.83654$

S.E. of regression $\quad 43.11927$ Akaike info criterion $\quad 10.40578$

Sum squared resid $\quad 349543.0 \quad$ Schwarz criterion $\quad 10.53958$

Log likelihood $\quad$-1011.766 Hannan-Quinn criter. $\quad 10.45995$

F-statistic $\quad 32.30152$ Durbin-Watson stat $\quad 1.130590$

Prob(F-statistic) $\quad 0.000000$

Here the stock return was considered to be dependent variable and the financial ratios such as dividend yield, earning yield and earnings per share were considered to be independent variables. 


\subsection{Hypotheses Testing}

$\mathrm{H}_{1}$ : There is a significant relationship between stock returns and dividend yield in the listed Manufacturing companies in Colombo Stock Exchange.

According to the regression summary the coefficient of the dividend yield is negative at a value of -0.108152 and which is significant since $\mathrm{p}$ value is less than 0.05 . Therefore $\mathrm{H}_{1}$ is supported at $5 \%$ significance level.

$\mathrm{H}_{2}$ : There is a significant relationship between stock returns and earning yieldin the listed Manufacturing companies in Colombo Stock Exchange.

The coefficient of the earning yield is 1.611117 which is also significant since p value is .0095 standard error and t statistics are found respectively 0.306184 and $5.261919 . \mathrm{H}_{2}$ is also supported at $5 \%$ significant level.

$\mathrm{H}_{3}$ : There is a significant relationship between stock returns and EPS in the listed Manufacturing companies in Colombo Stock Exchange.

According to the results of the regression, the coefficient value of earning per share, standard error and $t$ statistics are found respectively $-0.197892,0.086024$ and -2.300441 .Besides $P$ value is found to be less than $0.05(\mathrm{p}=0.0225)$. So $\mathrm{H}_{3}$ is supported. This implies that an increase in the earning per share by 1 Rupees is associated with a decrease in stock return by. 197892 .

The adjusted R2 value for the regression model is 0.546015 . Therefore it is possible to say that nearly $55 \%$ of the variations in the stock return could be explained by the variation in the dividend yield, earning yield and EPS remaining $45 \%$ not explained by this model.

\subsection{Test for Autocorrelation}

The residual is correlated with lagged values of itself which is not desirable. This study adopted Breusch Godfrey Serial Correlation LM Test to test for the presence of serial correlation on the residuals. The null hypothesis is of no serial correlation.

Table 5.Breusch-Godfrey serial correlation LM test

Breusch-Godfrey Serial Correlation LM Test:

\begin{tabular}{llll}
\hline F-statistic & 1.190535 & Prob. F(2,182) & 0.3064 \\
\hline Obs*R-squared & 2.401976 & Prob. Chi-Square(2) & 0.3009 \\
\hline
\end{tabular}

According to the above Table 5 the null hypotheses is accepted. There is no serial correlation.

\section{Recommendations for Future Study}

This research had the focus only on the manufacturing companies listed in CSE. The future research can undertake the research including other sectors such as Banking and finance. Trading sector, Diversified holding and Hotels and Tours Industries. 


\section{Mll Macrothink}

International Journal of Accounting and Financial Reporting

ISSN 2162-3082

2018, Vol. 8, No. 4

Here the financial ratio earning per share. dividend yield and earning yield were taken into consideration. The future researches can undertake the research paying attention to other financial ratios such as liquidity and working capital ratios.

\section{Conclusion}

After the end of the internal conflict in 2009, the share market activities have made remarkable country wise development. The CSE has established its branches in Kandy and Jaffna districts. Moreover the number of the investors in the share market is also on the increase. The purpose of the stock market investors is to get an income from their share market investment. The selection of the best shares will carry highest income. It is compulsory for the share market investors to guess the profitability of the company's shares in the past. This research has exposed the significant impact of financial ratios of stock return of the manufacturing companies. The results reveal that Earning yield has positive impact on share price of Listed Manufacturing companies. So the share market investors can obtain the highest income through their investment in the companies which have earning yield at the highest level.

\section{References}

Kanas, A., \&Yannopouluos, A. (2001). Comparing linear and nonlinear forecasts for stock returns.

Chairakwattana, K., \& Nathaphan, S. (2014). Stock Return Predictability by Baysian Model Averaging: Evidence from Stock Exchange of Thailand. International Journal of Economic Sciences, 3(1), 47-63.

Chaturika Seneviratne, S. M., \& Nimal, P. D. (2007). Size and book to market factors in explaining equity returns and earnings: evidence from Sri Lanka, pp.458-466.

Dissabandara, D. B. P. H. (2001). Dividend signaling market response to dividend change and capital market efficiency: An empirical analysis. Annual Research Session, Faculty of Management and Commerce, University of Sri Jayewardenepura.

Dissabandara, D. B. P. H., \& Samarakoon, L. P. (2002).Dividend announcements, firm size and dividend growth in the Sri Lankan Stock Market. Sri Lankan Journal of Management, 7.

Gunasekara, M. D. T. (2006). Share price reactions to bonus issue announcements of Sri Lankan Stock Market. University of Moratuwa, Sri Lanka

Kheradyar, S., Ibrahim, I., \& Nor, F. M. (2011). Stock return predictability with financial ratios. International Journal of Trade, Economics and Finance, 2(5).

Lewellen, J. (2004). Predicting stock returns with financial ratios. Journal of Financial Economics, 74, 209-235.

McMilian, D. (2001). Nonlinear predictability of stock market returns: Evidence from nonparametric and threshold models. International Review of Economics and Finance, 10, 353-368. 


\section{Macrothink}

International Journal of Accounting and Financial Reporting

ISSN 2162-3082

2018, Vol. 8, No. 4

Perera, R. A. A. S., \& Thrikawala, S. S. (2010).An empirical study of the relevance of accounting information on investor's decisions, ICBI, University of Kelaniya, Sri Lanka.

Rathnayaka, R., Nagahawatta, S. C., \& Seneviratna, D. (2014). Empirical Investigation of Stock Market Behavior in the Colombo Stock Exchange. Reshaping Management and Economic Thinking through Integrating Eco-Friendly and Ethical Practices (pp. 209-210).

Samarakoon, L. P. (1998). An Empirical Analysis of the Relationship between Fundamentals and Stock Returns in Sri Lanka.

Schrimpf, A. (2010). International Stock Return Predictability under Model Uncertainty. Journal of International Money and Finance, 29, 1256-1282.

Spiro, P. S. (1990). The impact of interest rate changes on stock price volatility. Journal of Portfolio Management, 16(2), Winter, 63-68.

Tan, H., Prokhorov, K., \& Wunsch, K. (1995). Conservative Thiry Calendar Stock Prediction Using a Probabilistic Neural Networks (pp. 113-117). Proceedings of Computational Intelligence for Financial Engineering Conference, Piscataway, NJ, USA.

Wijesundera, et al. (2015, July-December). Predictability of Stock Returns Using Financial Ratios: Empirical Evidence from Colombo Stock Exchange, Kelaniya. Journal of Management, 4(2).

Welth and Goyal (2007). A Comprehensive Look at the Empirical Performance of Equity Premium Prediction. Oxford University Press on behalf of The Society for Financial Studies. Advance Access publication.

Kuo, R. J., Chen, C. H., \& Hwang, Y. C. (2001). An intelligent stock trading decision support system through integration of genetic algorithm based fuzzy neural network and artificial neural network. Elsevier, 118(1).

\section{Copyright Disclaimer}

Copyright for this article is retained by the author(s), with first publication rights granted to the journal.

This is an open-access article distributed under the terms and conditions of the Creative Commons Attribution license (http://creativecommons.org/licenses/by/4.0/) 